\title{
PREDIKSI INFLASI DI INDONESIA MENGGUNAKAN METODE MOVING AVERAGE, SINGLE EXPONENTIAL SMOOTHING DAN DOUBLE EXPONENTIAL SMOOTHING
}

Nugroho Arif Sudibyo ${ }^{1}$, Ardymulya Iswardani ${ }^{2}$, Arif Wicaksono Septyanto ${ }^{3}$, Tyan Ganang Wicaksono ${ }^{4}$

1,2,3,4 Universitas Duta Bangsa Surakarta

nugroho_arif@udb.ac.id ${ }^{1}$, ardymulya@udb.ac.id², arif_wicaksono@udb.ac.id ${ }^{3}$, tiyan_ganang@udb.ac.id ${ }^{4}$

\section{Abstract:}

The purpose of this study is to find out the best forecasting model used to forecast inflation in Indonesia with inflation data from January 2015 to May 2020. This study uses several forecasting methods. Based on the forecasting method, the best forecasting results based on MAPE, MAD, and MSD are single exponential smoothing. Furthermore, the forecast results show that the inflation rate in Indonesia in August 2020 is 1.41746\%.

Keywords: Prediction, Inflation, Indonesia.

\begin{abstract}
Abstrak :
Tujuan dari penelitian ini adalah untuk mengetahui model peramalan yang paling baik digunakan untuk meramalkan inflasi di Indonesia dengan data inflasi Januari 2015 sampai dengan Mei 2020. Penelitian ini menggunakan beberapa metode peramalan. Berdasarkan metode peramalan yang dilakukan didapatkan hasil peramalan yang paling baik dilihat dari MAPE, MAD dan MSD adalah single exponential smoothing. Selanjutnya, hasil peramalan menunjukkan bahwa tingkat inflasi di Indonesia pada Agustus 2020 sebesar 1,41746\%.
\end{abstract}

Kata Kunci : Prediksi,Inflasi, Indonesia. 
Jurnal Lebesgue : Jurnal IImiah Pendidikan Matematika, Matematika dan Statistika

Nugroho Arif Sudibyo, Ardymulya Iswardani, Arif Wicaksono Septyanto, Tyan Ganang Wicaksono

Volume 1, No. 2, Agustus 2020 hal.123-129

DOI Artikel : 10.46306/lb.v1i2.25

\section{PENDAHULUAN}

Pada awal Desember 2019, korban COVID-19 pertama didiagnosis dengan coronavirus di Wuhan, Cina. Pada minggu-minggu berikutnya, penyakit ini menyebar luas di daratan Cina dan negaranegara lain, yang menyebabkan kepanikan global. Untuk memblokir penyebaran virus, ada beberapa strategi seperti penguncian di seluruh kota, penghentian lalu lintas, manajemen komunitas, jarak sosial, dan propaganda pengetahuan pendidikan kesehatan yang telah diadopsi oleh pemerintah China dan negara-negara lain di dunia (Chen, Lu, Chang, \& Liu, 2020).

Pandemi virus corona COVID-19 telah menghadirkan kesulitan baru bagi negara tersebut untuk bertahan hidup. Secara khusus, untuk lebih spesifik tentang bagaimana negara bereaksi dan mencoba untuk mencegah dan menghentikan penyebaran infeksi COVID-19 jauh lebih luas. Banyak negara menyelesaikan pendekatan yang diterapkan di wilayah mereka, misalnya, strategi penguncian, atau pengaturan untuk menjaga penghapusan sosial atau pemisahan sosial dari jaringan. Beberapa negara menunjukkan prestasi, namun beberapa menunjukkan kekecewaan dari pendekatan ini (Valerisha \& Putra, 2020). Indonesia merupakan negara yang juga terdampak pandemi COVID-19 (Sari, 2020).

Perekonomian Indonesia mengalami berbagai dampak akibat dari pandemi COVID-19 yang terjadi Sulit untuk mengatasi masalah kehidupan sehari-hari. Untuk mengatasi masalah sehari-hari dan ada juga banyak tantangan yang didapat dari semua segmen ekonomi di segala bidang juga merasakan dampak COVID-19 (Hanoatubun, 2020).

Inflasi merupakan indikator dalam menganalisis perekonomian suatu negara karena mempengaruhi mobilisasi dana lewat lembaga keuangan baik formal maupun non formal (Endri, 2008). Inflasi adalah meningkatnya harga-harga secara umum dan terus menerus. Peramalan inflasi di Indonesia mendapatkan perhatian penting bagi peneliti makro ekonomi. Untuk pertimbangan mengambil kebijakan moneter, sebagian besar bank sentral menggunakan inflasi sebagai salah satu acuan (Stephani, Suharsono, \& Suhartono, 2015).

Pesatnya perkembangan statistik pada era sekarang ini serta pada setiap aspek kehidupan dapat diterapkan. Perkembangan statistik memberikan gambaran bahwa statistik merupakan ilmu yang sangat berhubungan dengan data. Data sebelumnya merupakan data yang diperlukan dalam proses peramalan yang akan ditelaah, dan dianalis, serta dikaitkan dengan perjalanan waktu. Peramalan berhubungan erat dengan berjalannya waktu sehingga dapat memprediksikan data dimasa mendatang. Penggunaan peramalan telah membantu dengan baik dalam berbagai management sebagai dasar planing, pengawasan, dan pengambilan kebijakan dalam menentukan sebuah keputusan (Aden \& Supriyanti, 2020).

Beberapa penelitian yang terkait peramalan tingkat inflasi adalah sebagai berikut. Peramalan menggunakan double exponential smoothing dilakukan dengan memakai data inflasi bulanan di Indonesia periode 9 tahun untuk 4 tahun depan (Mahmudi, Irwandi, Rahmadaini, \& Fadhilah, 2018). 
Selanjutnya, untuk memprediksi tingkat inflasi bulanan di indonesia digunakan prediksi neural network dengan backpropagation. Dari penelitian yang telah dilakukan dapat disimpulkan bahwa prediksi neural network dengan backpropagation memberikan tingkat akurasi prediksi tinggi (Amrin, 2014). Disisi lain, dengan menggunakan periode 14 tahun, menunjukkan bahwa model yang digunakan yaitu model ARIMAX dan ANFIS hasilnya tingkat akurasinya tidak begitu tinggi (Stephani et al., 2015).

Berdasarkan uraian yang sudah dilakukan, tujuan dari penelitian ini adalah untuk mengetahui model peramalan yang paling baik digunakan untuk meramalkan inflasi di Indonesia dengan data inflasi Januari 2015 sampai dengan Juli 2020. Perhitungan peramalan dilakukan secara manual kemudian dicek dan divisualisasikan dengan software Minitab.

\section{METODE PENELITIAN}

Metode penelitian yang diterapkan adalah studi literature. Langkah-langkah yang dilakukan unutk mencapai tujuan dalam penelitian ini adalah sebagai berikut.

1. Menentukan batasan, asumsi dan parameter yang diperlukan untuk kontruksi model.

2. Mengkontruksi model berdasarkan batasan,asumsi dan parameter yang telah ditentukan.

3. Menentukan nilai parameter dan nilai awal pada kasus yang diamati.

4. Melakukan simulasi numerik menggunakan nilai parameter bervariasi.

5. Menginterpretasikan hasil yang diperoleh dari Lankah 4.

\section{HASIL DAN PEMBAHASAN}

Data penelitian diambil dari Januari 2015 sampai dengan Mei 2020 yang diambil dari Bank Indonesia (Bank Indonesia, 2020). Hasil analisis deskriptif yang diperoleh disajikan pada tabel 1.

Tabel 1. Analisis Deskriptif Statistik

\begin{tabular}{lccc}
\hline Variabel & Mean & Std.Deviation & N \\
\hline Inflasi & 3,827 & 1,393 & 67 \\
\hline
\end{tabular}

Setelah diketahui hasil analisis deskriptif akan dilakukan peramalan dengan tiga metode yaitu moving average (MA), single exponential smoothing (SES) dan double exponential smoothing (DES). Pada Gambar 1 merupakan moving average dengan length 3. 


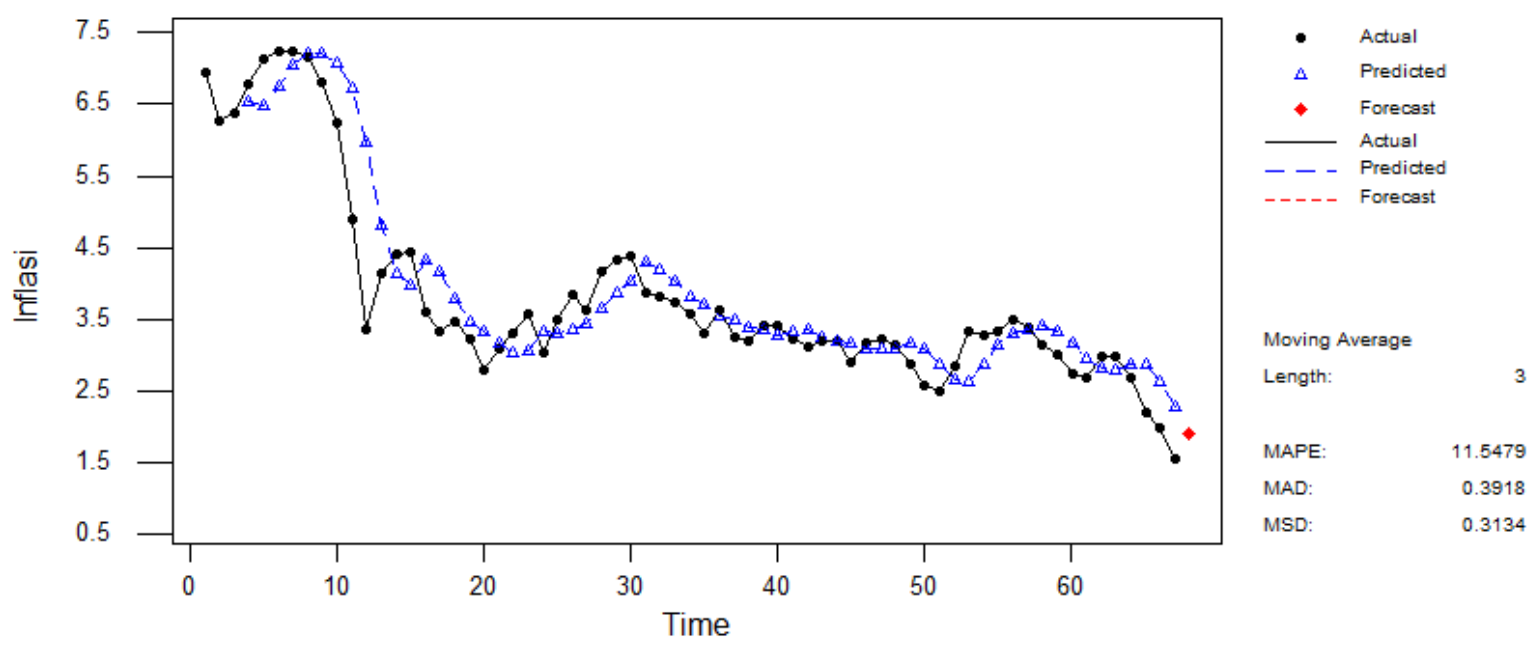

Gambar 1. Moving average dengan length 3.

Output Minitab menunjukkan bahwa MAPE sebesar 11,5479, MAD sebesar 0,3918 dan MSD sebesar 0,3134. Akan bangun model peramalan moving average dengan length 6, disajikan pada Gambar 2.

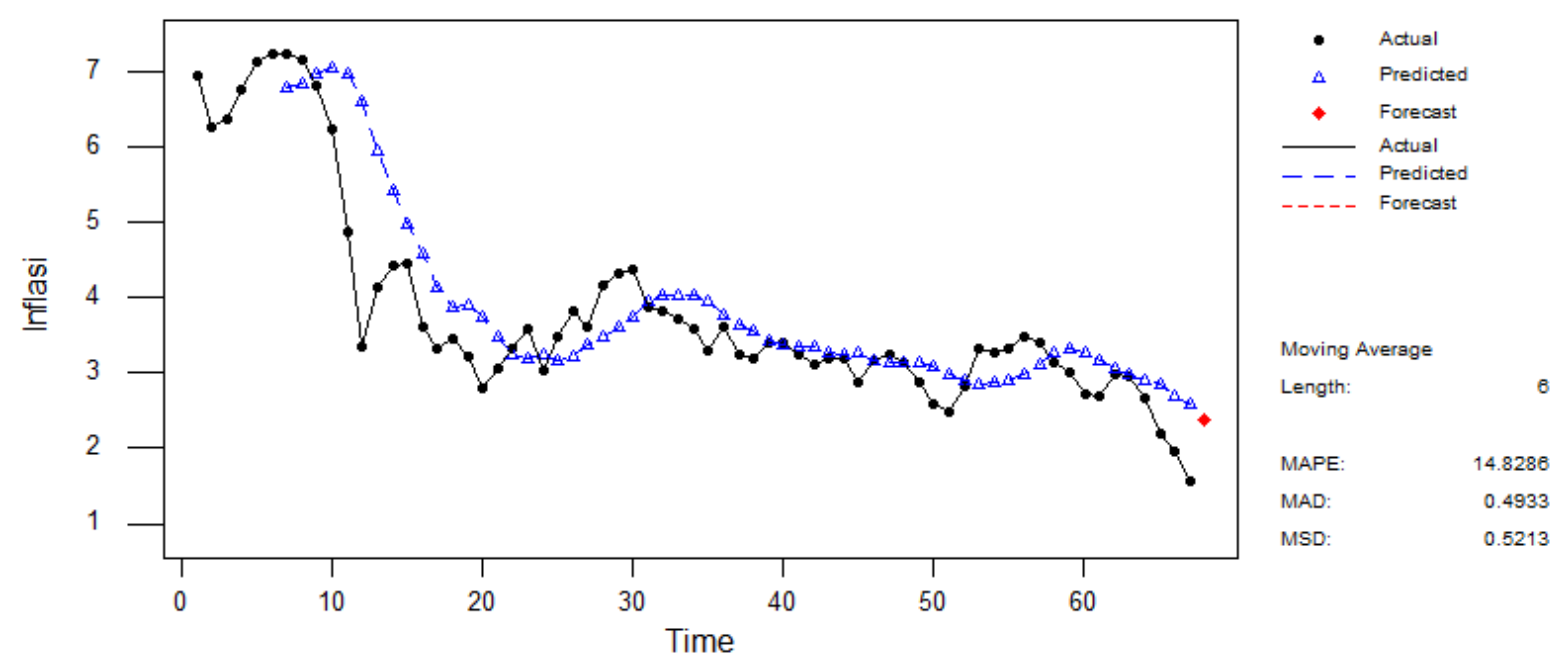

Gambar 2. Moving average dengan length 6 .

Output Minitab menunjukkan bahwa MAPE sebesar 14,8286, MAD sebesar 0,4933 dan MSD sebesar 0,5213. Selanjutnya, akan dibangun model peramalan dengan single exponential smoothing. Nilai parameter Alpha ditentukan setelah melakukan serangkaian simulasi, sehingga diperoleh nilai Alpha sebesar 1,316. Pada Gambar 3 merupakan model peramalan single exponential smoothing dengan nilai Alpha sebesar 1,316. 


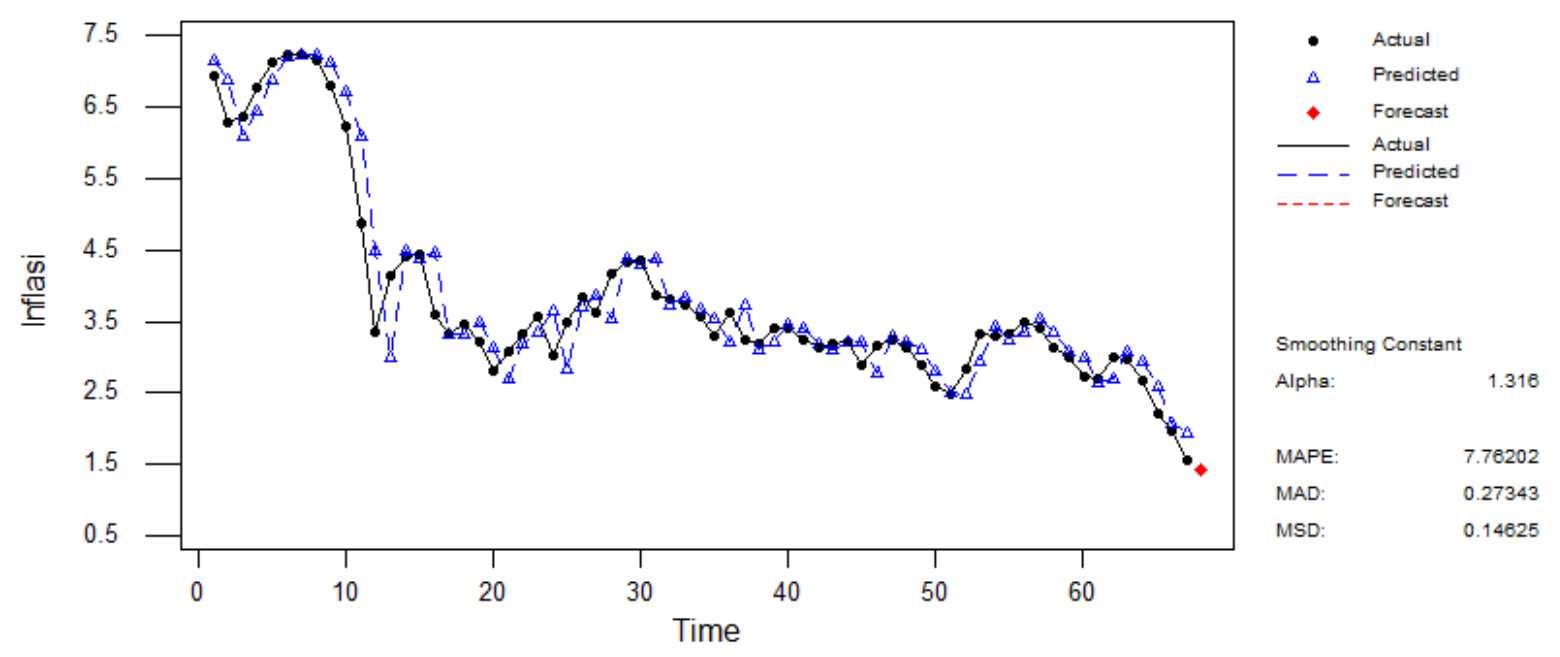

Gambar 3. Single exponential smoothing dengan nilai Alpha sebesar 1,316.

Output Minitab menunjukkan bahwa MAPE sebesar 7,76202, MAD sebesar 0,27343 dan MSD sebesar 0,14625. Selanjutnya, akan dibangun model peramalan dengan double exponential smoothing. Nilai parameter Alpha dan Gamma ditentukan setelah melakukan serangkaian simulasi, sehingga diperoleh nilai Alpha sebesar 1,321 dan Gamma sebesar 0,027. Pada Gambar 4 merupakan model peramalan double exponential smoothing dengan nilai Alpha sebesar 1,321 dan Gamma sebesar 0,0027.

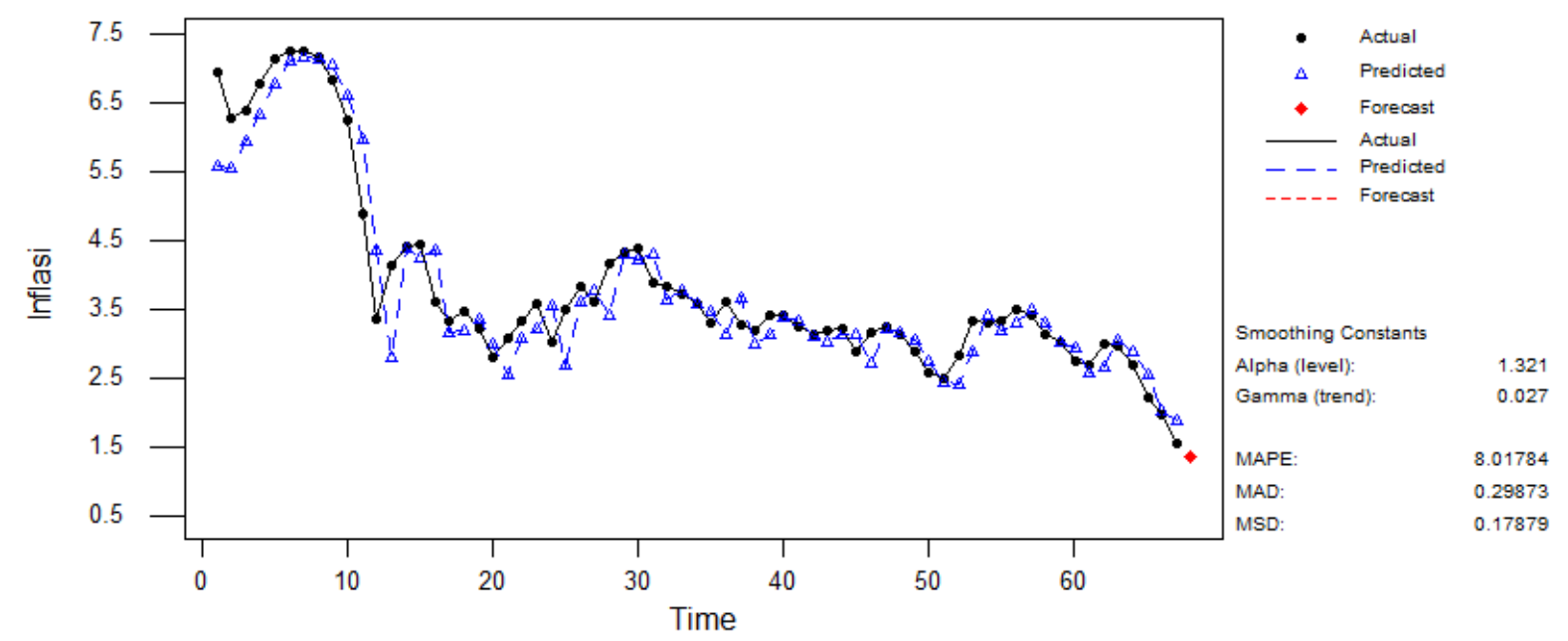

Gambar 4. Double exponential smoothing dengan nilai Alpha sebesar 1,321 dan Gamma sebesar

$$
0,0027 .
$$

Output Minitab menunjukkan bahwa MAPE sebesar 8,01784, MAD sebesar 0,29873 dan MSD sebesar 0,17879. Untuk lebih jelasnya, akan dibuat tabel perbandingan seperti pada Tabel 2. 
Tabel 2. Tabel perbangingan metode peramalan

\begin{tabular}{lccc}
\hline Metode Peramalan & MAPE & MAD & MSD \\
\hline Moving average dengan length 3 & 11,5479 & 0,3918 & 0,3134 \\
\hline Moving average dengan length 6 & 14,8286 & 0,4933 & 0,5213 \\
\hline Single exponential smoothing & 7,76202 & 0,27343 & 0,14625 \\
\hline Double exponential smoothing & 8,01784 & 0,29873 & 0,17879 \\
\hline
\end{tabular}

Dari Tabel 2 dapat dilihat bahwa metode single exponential smoothing (SES) merupakan metode paling baik dilihat dari MAPE, MAD dan MSD. Oleh karena itu, ingin diramalkan tingkat inflasi Indonesia pada bulan Agustus dengan metode tersebut. Dari hasil perhitungan single exponential smoothing dengan nilai Alpha sebesar 1,321, dapat diketahui bahwa tingkat inflasi bulan Agustus 2020 sebesar 1,41746\%. Pada bulan Desember 2019 sampai dengan Juli 2020 terjadi tren penurunan tingkat inflasi di Indonesia.

Tren penurunan tingkat inflasi yang terjadi terus-menerus dapat memberikan dampak yang negatif bagi perekonomian di Indonesia apalagi sejak awal tahun trennya cenderung turun. Artinya bahwa inflasi berpengaruh terhadap pertumbuhan ekonomi (Yulianti \& Khairuna, 2019). Hasil peramalan menunjukkan bahwa tingkat inflasi di Indonesia pada Juni 2020 sebesar 2,06472\%, hal tersebut menunjukkan bahwa tingkat inflasi dibawah target pemerintah sebesar 3\% (Bank Indonesia, 2018). Hal ini sebaiknya menjadi perhatian pemerintah pusat karena ditakutkan tren penurunan inflasi ini terus berlanjut akan berpengaruh pada pertumbuhan ekonomi di Indonesia.

Inflasi merupakan kenaikan harga barang-barang dan jasa yang salah satunya disebabkan oleh melonjaknya permintaan dari pasar, sehingga daya beli masyarakat Indonesia yang lemah bisa menurunkan tingkat inflasi. Daya beli masyarakat yang lemah salah satu faktor penyebabnya adalah pandemi COVID-19 (Sheth, 2020). Pandemi COVID-19 menyebabkan Indonesia mengambil langkah preventif yang menyebabkan daya beli masyarakat menjadi lemah. Apabila tidak segera dilakukan tindakan preventif, tren penurunan inflasi diIndonesia terus berlanjut yang secara tidak langsung berdampak pada perekonomian di Indonesia.

\section{KESIMPULAN}

Berdasarkan penelitian yang telah dilakukan, didapat kesimpulan bahwa metode peramalan yang paling baik dilihat dari MAPE, MAD dan MSD adalah single exponential smoothing. Selanjutnya, hasil peramalan menunjukkan bahwa tingkat inflasi di Indonesia pada Agustus 2020 sebesar 1,41746\%.. 


\section{DAFTAR PUSTAKA}

Aden, \& Supriyanti, A. (2020). PREDIKSI JUMLAH CALON PESERTA DIDIK BARU MENGGUNAKAN METODE DOUBLE EXPONENTIAL SMOOTHING DARI BROWN ( Study Kasus: SD Islam Al-Musyarrofah Jakarta ). Jurnal Lebesgue : Jurnal Ilmiah Pendidikan Matematika, Matematika Dan Statistika, 1(1), 56-62. https://doi.org/10.46306/lb.v1i1

Amrin, A. (2014). Peramalan Tingkat Inflasi Indonesia Menggunakan Neural Network Backpropagation Berbasis Metode Time Series. Tecno Nusa Mandiri, 11(2), 129-136. https://doi.org/10.31227/osf.io/7hsp2

Bank Indonesia. (2018). Penetapan Target Inflasi. Retrieved from https://www.bi.go.id/id/moneter/inflasi/bi-dan-inflasi/Contents/Penetapan.aspx

Bank Indonesia. (2020). Data Inflasi BI. Retrieved from https://www.bi.go.id/id/moneter/inflasi/data/Default.aspx

Chen, Y.-C., Lu, P.-E., Chang, C.-S., \& Liu, T.-H. (2020). A Time-dependent SIR model for COVID-19 with Undetectable Infected Persons. 1-18. Retrieved from http://arxiv.org/abs/2003.00122

Endri. (2008). ANALISIS FAKTOR-FAKTOR YANG MEMPENGARUHI INFLASI DIINDONESIA. Jurnal Ekonomi Pembangunan, 13(1), 1-13.

Hanoatubun, S. (2020). DAMPAK COVID - 19 TERHADAP PEREKONOMIAN INDONESIA. EduPsyCouns Journal, 2(1), 146-153.

Mahmudi, M., Irwandi, R., Rahmadaini, R., \& Fadhilah, R. (2018). Meramalkan Laju Inflasi Menggunakan Metode Pemulusan Eksponensial Ganda. Journal of Data Analysis, 1(1), 12-20. https://doi.org/10.24815/jda.v1i1.11863

Sari, Y. I. (2020). Sisi Terang Pandemi COVID-19. Jurnal Ilmiah Hubungan Internasional, O(0), 8994. https://doi.org/10.26593/JIHI.V0I0.3878.89-94

Sheth, J. (2020). Impact of Covid-19 on consumer behavior: Will the old habits return or die? Journal of Business Research, 117, 280-283. https://doi.org/10.1016/j.jbusres.2020.05.059

Stephani, C. A., Suharsono, A., \& Suhartono. (2015). Peramalan Inflasi Nasional Berdasarkan Faktor Ekonomi Makro Menggunakan Pendekatan Time Series Klasik dan ANFIS. Sains Dan Seni ITS, $4(1), 67-72$.

Valerisha, A., \& Putra, M. A. (2020). Pandemi Global COVID-19 dan Problematika Negara-Bangsa: Transparansi Data Sebagai Vaksin Socio-digital? Jurnal Ilmiah Hubungan Internasional, 131137. Retrieved from https://doi.org/10.26593/jihi.v0i0.3871.131-137

Yulianti, R., \& Khairuna. (2019). PENGARUH INFLASI TERHADAP PERTUMBUHAN EKONOMI PROVINSI ACEH PERIODE 2015- 2018 DALAM PRESPEKTIF EKONOMI ISLAM. AKUNTANSI MUHAMMADIYAH, 9(2), 113-123. 